\title{
スクロース処理が蕾切りカーネーションの切り花品質および糖質濃度に及ぼす影響
}

\author{
水口 $\quad$ 聡 $^{1 *} \cdot$ 市村一雄 ${ }^{2} \cdot$ 久松 完 $^{2} \cdot$ 腰岡政二 ${ }^{2}$ \\ 1 愛媛県農業試験場 799-2405 松山市上難波 \\ 2 花き研究所 $305-8519$ つくば市藤本
}

\section{Effects of Treatment with Sucrose on Qualities and Sugar Concentrations of Bud Cut Carnations}

\author{
Satoshi Minakuchi ${ }^{1 *}$, Kazuo Ichimura ${ }^{2}$, Tamotsu Hisamatsu ${ }^{2}$ and Masaji Koshioka ${ }^{2}$ \\ ${ }^{1}$ Ehime Agricultural Experiment Station, Matsuyama, Ehime 799-2405 \\ ${ }^{2}$ National Institute of Floricultural Science, Tsukuba, Ibaraki 305-8519
}

\begin{abstract}
Effect of sucrose concentration on flower qualities and changes in sugar concentrations during bud development in carnations (Dianthus caryophyllus L. 'Nora') were investigated. Bud cut carnation flowers were treated with sucrose solutions ranging from $0 \%$ to $17 \%$ at $23^{\circ} \mathrm{C}$. Sucrose concentrations had no influence on the number of days from bud to full bloom. Sucrose at high concentrations was effective in increasing the flower diameter and improved petal color pigmentation. In the calyx, leaf and stem of intact carnations, concentrations of pinitol, sucrose, glucose and fructose remained almost constant during bud development. In petals of intact carnations, concentrations of fructose and glucose increased markedly with bud development. In all organs of bud cut carnations treated with $0 \%$ sucrose, concentrations of these sugars, except for pinitol, decreased markedly and remained very low during the experimental period. Decrease in the sugar concentrations in all organs was suppressed by $5 \%$ sucrose treatment, although the concentrations were relatively low levels compared with those of the intact carnation. These findings suggest that sucrose increases sugar concentrations in petals, which may improve flower size and petal color pigmentation of bud cut carnations.
\end{abstract}

Key Words : bud anthesis acceleration (BAA), flower diameter, petal color pigmentation, pinitol

キーワード : 花径, 花色発現, ピニトール, 蕾開花促進

\begin{abstract}
緒 言
カーネーションの需要は母の日前に急増し市場価格が高 くなるが，母の日を過ぎると大きく下落する，そのため， 母の日用として出荷できなかったカーネーションのほとん どは廃棄されている. カーネーションの開花は温度の影響 を大きく受ける（Abou Dahab, 1967; Teklic ら，2003）ため, 生産現場では八ウス内を加温することによりできるだけ生 育を早めて，母の日に間に合わないものを少なくしている のが現状である。しかしこの場合，多大な燃料費が必要に なるだけでなく，母の日用としては蕾の生育が早すぎるも のの割合が多くなり，それらは母の日用に出荷するために 低温貯蔵を行う必要が生じ，このことが品質低下の要因と なっている.

これまでに, カーネーションの出荷調節のために蕾状態 で採取した後低温で貯蔵し, 出荷前に開花させる手法の検
\end{abstract}

2006 年 12 月 12 日 受付. 2007 年 3 月 1 日 受理.

本研究の一部は園芸学会平成 11 年度秋季大会で発表した.

*Corresponding author. E-mail: minakuchi-satoshi@pref.ehime.jp
討が数多くなされてきた (Cywińska ら, 1978; Goszczyńska・ Rudnicki, 1983; Kofranek ら, 1972; 小山・宇田, 1994a, b; Rudnicki ら，1989)。これらは収穫後の低温貯蔵と強制開花 を組み合わせた，いわゆる開花を遅らせる出荷調節法と言 える，一方，Minakuchi ら（2004）は逆に開花を促進し，母 の日用出荷が見込めないものだけを若い蕾のステージで採 取し，栄養分を与えるとともに，光を照射しながら高温環 境下に保つことにより蕾の開花を早くする「蕾開花促進法」 の有用性を提案した. しかし, 蕾開花促進処理に打いては, 処理温度 $20^{\circ} \mathrm{C}, 25^{\circ} \mathrm{C}$ おび $30^{\circ} \mathrm{C}$ では温度が高いほど開花 所要日数は短くなるが, $20^{\circ} \mathrm{C}$ 処理では花の大きさが小さく 花持ちが悪くなり， $25^{\circ} \mathrm{C}$ 処理でも花持ちが悪化し， $30^{\circ} \mathrm{C}$ 処理では花弁の色調が大きく変化するなど，品質面にさま ざまな問題が残されている（水口ら，2005）.

一般に切り花の代謝糖とされるスクロース，グルコース 扣よびフルクトースのらち, 蕾収穫したカーネーション切 り花の開花促進にはスクロースが有効である（水口ら， 2007）. カーネーションでは, 植物で一般的な代謝糖であ るスクロース，グルコース抢よびフルクトースの他，ピニ トールが主要な構成糖質であることが報告されている 
(Ichimura ら，1998）。しかし, 蕾収穫したカーネーション 切り花を開花させるために処理した糖質が花弁中にどのよ らに蓄積されるかについてはこれまで報告されておらず, また内生のピニトールがどのような変動をするかについて もまったく明らかにされていない. そこで, 蕾切りカーネー ションの品質向上を目的に，スクロースが蕾生育拈よび切 り花品質に及ぼす影響を調査するとともに, 生育中の切り 花中糖質濃度の変化を解析した。

\section{材料および方法}

\section{1. 供試材料}

材料には1998年6月に三重県安濃町のガラス温室に定植 した淡桃色でスタンダード系の品種 ‘ラ’の 1 番花を供 試した。 そのまま温室内で生育させたものを自然生育区と した. 外側の花弁が水平になったときを満開とし, 満開に 達した時点で収穫したものを通常収穫区とした。

\section{2. スクロース処理}

1998 年 12 月に, 蕾の先端が少し開き花弁はまだ色づい ていない段階であるステージ 3 (Minakuchi ら，2004）で採 取し, 切り花長 $50 \mathrm{~cm}$ に切り揃え, 処理液に生け, 温度抒 よび相対湿度をそれぞれ $23^{\circ} \mathrm{C}$ 打よび $70 \%$ に制御した室内 で保持した. 処理液は $200 \mathrm{ppm}$ の 8- ハイドロキシキノリン 硫酸塩（8-HQS）と $25 \mathrm{ppm}$ の硝酸銀を共通成分とし，スク ロース濃度は $0,1 ， 3 ， 5 ， 7 ， 9 ， 11 ， 13 ， 15$ および $17 \%$ の 10 段階とした. 処理中の光環境は $10 \mu \mathrm{mol} \cdot \mathrm{m}^{-2} \cdot \mathrm{s}^{-1}$ で 12 時間日長とした，処理液の更新は行わず，切り口が処理 液に $3 \mathrm{~cm}$ 程度浸かった状態を維持するために補充するのみ とした。処理は蕾が満開になるまで継続し, これらを蕾収 穫区とした.

\section{3. 開花所要日数および品質調査}

処理開始から蕾が満開になるまでに要した日数を開花所 要日数とした. 通常収穫区および蕾収穫区ともに, 満開に 達した時点で，花径，花弁色調，切り花の先端から $25 \mathrm{~cm}$ 付近の葉 (中位葉) の色調, 拈よび下垂度を測定し, 前処 理を施してから花持ちを調査した. 各試験区ともに 7 本ず つ供試した.

花径は満開時の花の直径とした. 花と葉の色調について は十分に展開した花弁および中位葉の中央部の色調をミノ ルタ社の色彩計 Minolta Chroma Meter CR-200b を用いて, 明 度（L*）执よびクロマティクネス指数（ $\mathrm{a}^{*}$ および $\mathrm{b}^{*}$ )を 測定した. 測定值から $\mathrm{C}^{*}=\left(\mathrm{a}^{* 2}+\mathrm{b}^{* 2}\right)^{1 / 2}$ の式により彩度, $\mathrm{h}^{\circ}=\operatorname{ATAN}\left(\mathrm{b}^{*} / \mathrm{a}^{*}\right) / 6.2832 \times 360$ の式により花弁の色相角度, $\mathrm{h}^{\circ}=\operatorname{ATAN}\left(\mathrm{b}^{*} / \mathrm{a} *\right) / 6.2832 \times 360+180$ の式により中位葉の色相 角度をそれぞれ算出した（McGuire, 1992)。垂度について は, 切り花を水平に保ち, 切り口から $5 \mathrm{~cm}$ までを固定し花 が下垂した角度を測定した. 前処理として, $0.5 \mathrm{mM}$ のオオ 硫酸銀錯塩（STS）を温度 $23^{\circ} \mathrm{C}$ ，相対湿度 $70 \%$ 条件下で 5 時間吸液させた. 前処理後, 切り花を水道水に生け $10 \mu \mathrm{mol}$ ・ $\mathrm{m}^{-2} ・ \mathrm{~s}^{-1}$ で 12 時間日長の光環境下に置き, 温度および相対
湿度をとれぞれ $23^{\circ} \mathrm{C}$ および $70 \%$ に制御した室内で保持 し，花弁が萎れ始めるまでの日数を花持ち日数とした.

\section{4. 部位別糖質分析}

自然生育区，スクロース $0 \%$ および $5 \%$ 処理区について, がく, 花弁, 中位葉および中位葉と同じ位置の茥 (中位茥) に含まれる糖質を分析した。自然生育区については，蕾収 穫日に同じステージ 3 のものにラベルを付け, 蕾収穫時, 5 日後，10 日後および 15 日後に糖質分析に供した. 1 回の抽 出には切り花 3 本を用い, 各試験区ともに 3 反復とした.

糖質の抽出は以下の手順で行った．各部位から約 $1 \mathrm{~g}$ ず つ採取し $80 \%$ エタノールを $10 \mathrm{~mL}$ 加光, $75^{\circ} \mathrm{C} て ゙ 30$ 分間加 熱処理した. 冷却後, 内部標準物質として $2.5 \%$ マンニトー ル水溶液を $100 \mu \mathrm{L}$ 加えホモジナイズし, 3,000 rpm で 10 分 間遠心分離後，上澄みを回収した．残さに $80 \%$ エタノール を $5 \mathrm{~mL}$ 加え再抽出した. 再抽出は2 回くり返した. 回収 した上澄みを遠心エバポレーターを用いて減圧乾固させ, $1 \mathrm{~mL}$ の蒸留水で再び溶解し, 抽出サンプルとした. 抽出サ ンプルを Sep-Pak プラス $\mathrm{C} 18$ に通し，さらに $2 \mathrm{~mL}$ の蒸留 水で洗った後, $0.45 \mu \mathrm{m}$ のィルターに通し, 高速液体ク ロマトグラフィーシステム（GULLIVER，日本分光）を用 いた糖質分析に供した。

HPLC 分析カラムには昭和電工社製の Shodex SUGAR SP0810を用いた. 溶離液には $0.45 \mu \mathrm{m}$ の Membrane filter で ろ過した蒸留水を用いた。 カラムの温度は $80^{\circ} \mathrm{C}$, 流速は $0.8 \mathrm{~mL} \cdot \mathrm{min}^{-1}$ とした. 検出器には示差屈折率検出器を用い た. 各種糖質の濃度はマンニトールを用いた内部標準法に て算出した.

\section{結果}

\section{1. スクロース濃度が開花に及ぼす影響}

本試験ではすべての処理区で 100\%開花した．第 1 表に 開花所要日数の結果を示す．0\%区と $1 \%$ 区で 16 日程度と やや長い傾向にあったが，分散分析の結果，統計的に有意 ではなかった。

Table 1 Effects of treatments with various concentrations of sucrose on time to flowering in bud cut carnations.

\begin{tabular}{cc}
\hline \hline $\begin{array}{c}\text { Sucrose concentration } \\
(\%)\end{array}$ & $\begin{array}{c}\text { Time to flowering } \\
\text { (days) }\end{array}$ \\
\hline 0 & $16.0 \pm 1.3$ \\
1 & $15.7 \pm 2.3$ \\
3 & $12.9 \pm 1.1$ \\
5 & $13.6 \pm 1.0$ \\
7 & $12.8 \pm 0.6$ \\
9 & $12.9 \pm 0.8$ \\
11 & $13.7 \pm 1.9$ \\
13 & $12.3 \pm 0.7$ \\
15 & $11.2 \pm 0.5$ \\
17 & $11.7 \pm 0.8$ \\
\hline
\end{tabular}

\footnotetext{
${ }^{\mathrm{z}}$ Values are means of seven replications \pm standard error.

${ }^{\mathrm{y}} \mathrm{NS}$ indicates nonsignificant by analysis of variance.
} 
Table 2 Effects of treatments with various concentrations of sucrose on flower qualities of fully opened flowers in bud cut carnations ${ }^{2}$.

\begin{tabular}{|c|c|c|c|c|c|c|c|}
\hline \multirow{2}{*}{ Harvesting stage } & \multirow{2}{*}{$\begin{array}{c}\text { Sucrose concentration } \\
(\%)\end{array}$} & \multirow{2}{*}{$\begin{array}{l}\text { Flower diameter } \\
\qquad(\mathrm{mm})\end{array}$} & \multicolumn{3}{|c|}{ Petal coloration } & \multirow{2}{*}{$\begin{array}{l}\text { Drooping index } \\
\quad \text { (degree) }\end{array}$} & \multirow{2}{*}{$\begin{array}{c}\text { Vase life } \\
\text { (days) }\end{array}$} \\
\hline & & & Lightness $\left(\mathrm{L}^{*}\right)$ & Chroma $\left(\mathrm{C}^{*}\right)$ & Hue angle $\left(\mathrm{h}^{\circ}\right)$ & & \\
\hline \multirow[t]{10}{*}{ Stage 3} & 0 & $63.3 \mathrm{c}^{\mathrm{y}}$ & $90.4 \mathrm{ab}$ & $9.3 \mathrm{e}$ & $51.7 \mathrm{a}$ & $11.8 \mathrm{bc}$ & $10.0 \mathrm{~d}$ \\
\hline & 1 & $63.7 \mathrm{c}$ & $90.7 \mathrm{a}$ & $9.9 \mathrm{e}$ & $55.5 \mathrm{a}$ & $9.7 \mathrm{bc}$ & $15.0 \mathrm{ab}$ \\
\hline & 3 & $69.9 \mathrm{bc}$ & $83.1 \mathrm{abc}$ & $12.4 \mathrm{de}$ & $23.1 \mathrm{~b}$ & $14.9 \mathrm{~b}$ & $14.4 \mathrm{~b}$ \\
\hline & 5 & $76.8 \mathrm{ab}$ & 81.8 bcd & $15.0 \mathrm{~cd}$ & $16.0 \mathrm{bc}$ & $15.1 \mathrm{~b}$ & $13.3 \mathrm{bc}$ \\
\hline & 7 & $77.2 \mathrm{ab}$ & $79.8 \mathrm{~cd}$ & $19.1 \mathrm{ab}$ & $11.8 \mathrm{bc}$ & $11.2 \mathrm{bc}$ & $12.5 \mathrm{bc}$ \\
\hline & 9 & $81.5 \mathrm{a}$ & $79.1 \mathrm{~cd}$ & $20.0 \mathrm{a}$ & $11.3 \mathrm{bc}$ & $10.6 \mathrm{bc}$ & $12.6 \mathrm{bc}$ \\
\hline & 11 & $80.5 \mathrm{a}$ & $77.6 \mathrm{~cd}$ & $21.5 \mathrm{a}$ & $10.0 \mathrm{c}$ & $9.5 \mathrm{bc}$ & $11.0 \mathrm{~cd}$ \\
\hline & 13 & $81.8 \mathrm{a}$ & $76.1 \mathrm{~cd}$ & $21.8 \mathrm{a}$ & $11.1 \mathrm{c}$ & $8.9 \mathrm{c}$ & $13.1 \mathrm{bc}$ \\
\hline & 15 & $79.4 \mathrm{a}$ & $75.1 \mathrm{~d}$ & $22.2 \mathrm{a}$ & $10.3 \mathrm{c}$ & $12.7 \mathrm{bc}$ & $17.8 \mathrm{a}$ \\
\hline & 17 & $83.4 \mathrm{a}$ & $77.3 \mathrm{~cd}$ & $20.3 \mathrm{a}$ & $10.7 \mathrm{c}$ & $12.3 \mathrm{bc}$ & $12.6 \mathrm{bc}$ \\
\hline Normal & - & $78.9 \mathrm{a}$ & $87.2 \mathrm{ab}$ & $16.7 \mathrm{bc}$ & $21.3 \mathrm{bc}$ & $25.0 \mathrm{a}$ & $17.5 \mathrm{a}$ \\
\hline
\end{tabular}

${ }^{\mathrm{z}}$ Values are means of seven replications.

${ }^{\mathrm{y}}$ Values with the same letters are not significantly different by Tukey-Kramer Procedure ( $95 \%$ confidence).

\section{2. スクロース濃度が切り花品質に及ぼす影響}

第 2 表に切り花品質の結果を示す.

通常収穫区の花径は $78.9 \mathrm{~mm}$ であった。蕾収穫後, スク ロース処理を行った場合，0\%，1\%拈よび3\%区では花径 が通常収穫区より有意に小さくなったが，処理液のスク ロース濃度が高くなるほど花径が大きくなり, $5 \%$ 以上の区 では通常収穫区と同等となった。

花弁色調について，明度は 0\%〜 5\%まで，彩度は 5\% 打 よび7\%区で, 色相角度は3\%以上の区でそれぞれ通常収穫 区と有意差がなかった，スクロース濃度が高いほど，明度 が低く，彩度が高く，色相角度が低くなる傾向が認められ た.すなわち，スクロース濃度を高くすることにより，花 弁の淡桃色が濃くあざやかになった。

葉の色調について．彩度拈よび色相角度には試験区間に 有意差は認められず，明度が蕾収穫した切り花でやや低く なる傾向にあったが，可視的には判別できない程度の差で あった（データ略）.

茎の下垂度について，蕾収穫区では通常収穫区より明ら かに下垂度が小さくなったが，スクロース濃度による顕著 な差は認められなかった。

花持ちについて, 蕾収穫区では 10 日以上の花持ちは確保 できたが，1\%区と $15 \%$ 区以外では通常収穫区と比較する と有意に花持ちが短くなった.

\section{3. スクロース処理が切り花中糖質濃度に及ぼす影響}

自然生育区，0\%区，5\%区ともに蕾の開花所要日数は注 ぼ同じで，いずれの区も 15 日目にほぼ満開となった。

切り花に打ける部位別糖質濃度の変化を第 1 図に示す。 HPLC 分析により，すべての部位でスクロース，グルコー ス，フルクトース，ピニトール拈よびミオイノトールが 検出された。ミオイノシトールはいずれの部位でもわずか な量しか存在していなかった。

自然生育区に打いては，がくでグルコースとフルクトー ス, 葉でピニトールおよびスクロース, 茎でピニトール,
スクロースおよびグルコースがそれぞれ主要な構成糖質 で，生育中の変化は少なかった，花弁では，いずれの糖質 も収穫時の若い蕾段階には $1 \mathrm{~g}$ 当たり $3 \mathrm{mg}$ から $8 \mathrm{mg}$ 程度 であったが，開花にともないグルコースとフルクトースが 顕著に増加した。

0\%区では，いずれの部位においても，開花にともないス クロース，グルコース抢よびフルクトースが著しく減少し たが，ピニトールのみは自然生育区と同程度でほぼ一定に 保たれていた.

5\%区では，いずれの部位の糖質濃度も自然生育区より 低い傾向にあったが，0\%区とは異なり，がくおよび茎の糖 質濃度の低下は緩やかであった。花弁では自然生育区ほど 顕著ではないものの，開花にともなら糖質濃度の上昇が認 められた． 特にグルコースとフルクトースの濃度増加が顕 著であったが，ピニトール濃度は自然生育区と同程度で注 ぼ一定に保たれていた。

\section{考察}

蕾の開花ではシンク器官である花弁に糖と水が急速に 蓄積し, 細胞が急激に肥大する (Kenis ら, 1985). 従って, 根からの養分供給が絶たれる蕾切りカーネーションを正 常に開花させ高い切り花品質を確保するためには, 糖質を 供給し花弁の糖質濃度を良好に保つことが重要である。そ こで，さまざまな濃度のスクロースを含む処理液を供試 し，蕾切りカーネーションの蕾生育拈よび切り花品質に及 ぼす影響を調査するとともに，スクロース処理が蕾生育中 の切り花の各部位に扣ける糖質濃度に及ぼす影響を明ら かにした。

その結果，処理液のスクロース濃度は開花所要日数には 顕著に影響しなかったが，高濃度のスクロース処理により 花径が大きくなり花色発現が促進された.

スクロースを切り花に処理することで，花弁中の糖質濃 度が高くなるとともに花弁の展開が促進される（Ichimura 

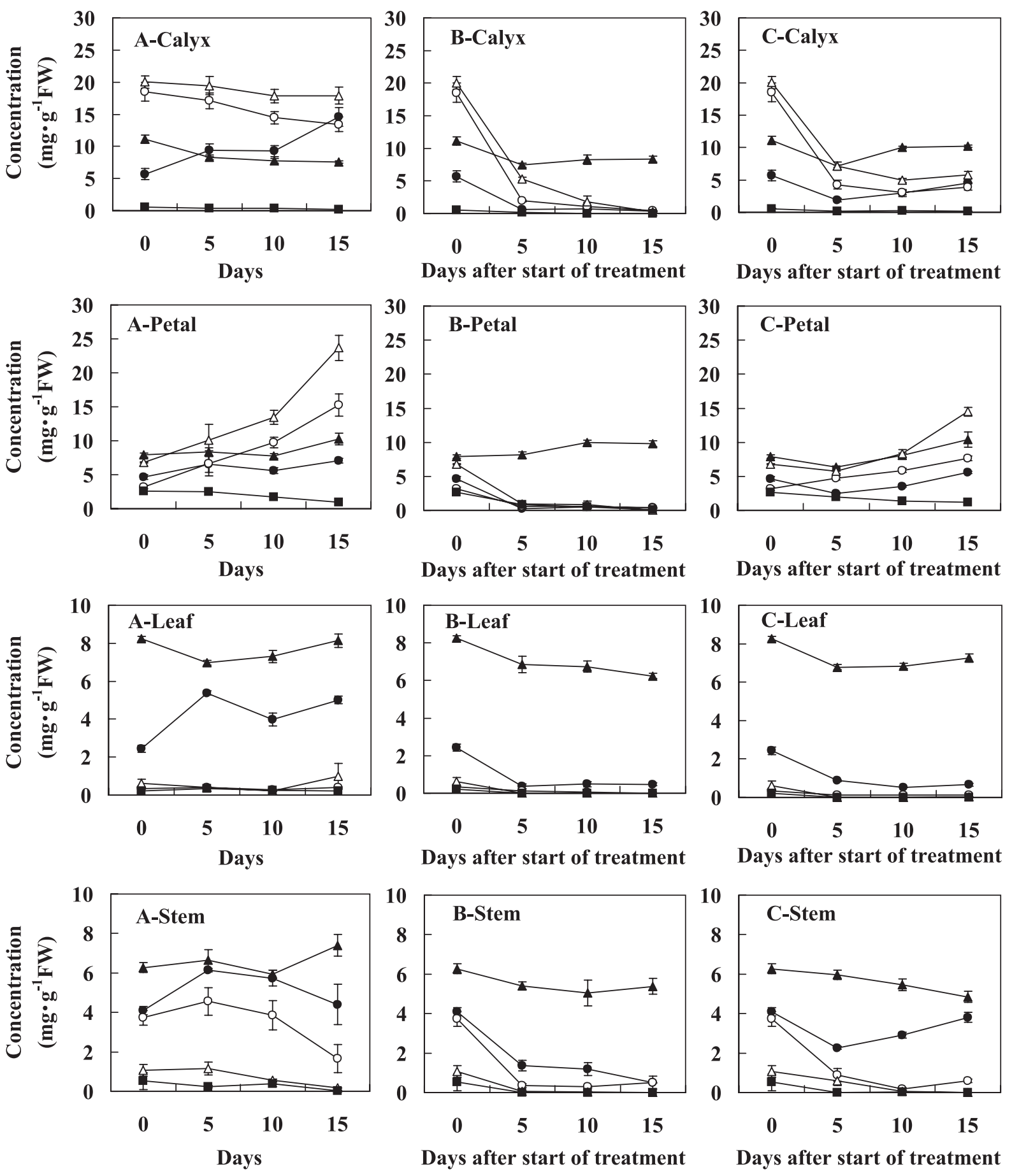

Fig. 1 Changes in carbohydrate concentrations in calyx, petal, leaf and stem of intact carnations growing in a greenhouse (A), bud cut carnations treated with $0 \%$ sucrose (B), treated with $5 \%$ sucrose $(\mathrm{C})$. Values are means of 3 replications \pm standard errors. Symbols indicate as follows; $\mathbf{O}$ : sucrose, $\bigcirc$ : glucose, $\mathbf{\Delta}$ : pinitol, $\triangle$ : fructose and $\boldsymbol{\square}$ : myo-inositol.

ら，1999）ことから，蕾切りカーネーションにおいて，ス クロース濃度を高くし花弁への糖質供給量を多くした本試 験の結果，花弁の肥大伸長が促進され，花径が大きくなっ たものと考光られる。通常收穫区と比較すると，0\%〜3\% 区では花弁伸長に必要な糖質が不足して沶り, 5\%以上の区 では十分な量の糖質を供給できていると推察された。

バラ，トルコギキョウ，スイートピー等で，スクロース
処理により花色の発現が促進されることが明らかとなって いる (Ichimura •Hiraya, 1999; Ichimura $・$ Korenaga, 1998; Parups• Chan, 1973). 今回, スクロース濃度が高い汪ど, 明度が低く, 彩度が高く, 色相角度が低くなる傾向が認められ, 通常収 穫区と比較して，0\%抢よび $1 \%$ 区では彩度拈よび色相角度 ともに劣り，3\%区では彩度が低く，5\%区では同等，7\%以 上の区では有意に彩度が高く花色発現が促進された。従っ 
て，スクロースを 5\%含む処理液を用いることにより，花 色発現のために必要な最低限の糖質は供給できていると推 察された。

本研究では, 蕾収穫したカーネーションの STS 処理を通 常收穫区と同じょうに開花後に行ったところ，10 日以上 の花持ちは確保できたものの，通常収穫区ょり劣る区が あった. 今後, 蕾開花促進処理前に STS 処理を行らなど, 蕾切りカーネーションに適した STS 処理条件の検討が必 要である.

次に，スクロース処理が蕾収穫した切り花中の糖質濃度 にどのような影響を与えるのか検証した

まず自然生育区では，がくと花弁に多量の糖質が蓄積し ており，特に花弁では開花にともないグルコースとフルク トース濃度が増加した。 この現象にはインベルターゼが関 与していることが明らかとなっている（Woodson・Wang, 1987).

ステージ 3 で採取した後スクロース処理を行った場合, 0\%区でも 100\%開花し，見かけ上は糖質を与えなくても十 分開花できるよらであったが，開花時の切り花中の糖質 は，がく，花弁，葉打よび茎のいずれの部位に颃いてもほ ぼ枯渴状態であった．特に花弁中の糖質不足は花径の低下 や花色発現不良の原因と考号られた。一方，5\%区では，が くや茥に打けるスクロース，グルコース执よびフルクトー スの低下が抑えられ，花弁ではグルコースおよびフルク トースの濃度上昇が認められた。すなわち，スクロース処 理は蕾切り花中の代謝糖を増加させ，このことが花径の増 大や花色発現の促進に寄与していると考兄られる.

自然生育区，0\%区拉よび5\%区のいずれに打いてもすべ ての部位でピニトール濃度だけがほとんど変化しなかっ た. ピニトールはカーネーション切り花中の主要な糖質で あり，グルコースやスクロースのよらな代謝糖とともに蕾 の生育や花弁の開花に寄与している可能性が報告されてい る (Ichimura ら，1998）。今回，代謝糖が不足していると考 えられる0\%区でも，ピニトール濃度だけは自然生育区や 5\%区と同じレベルで常に一定に保たれたことから，ピニ トールは代謝されにくい糖質であり, スクロース, グルコー ス，フルクトースのような代謝糖とは異なるはたらきをも つと考えられる.

以上のように，処理液中のスクロース濃度を高くするこ とは，開花所要日数にはあまり影響せず，切り花中の糖質 濃度を上昇させるとともに，花の大きさを増大し花色発現 を促進することが明らかとなった，従って，蕾開花促進法 に执いて，花の大きさが小さくなる場合や花弁の色調が大 きく変化する場合，処理液中のスクロース濃度を高くする ことで，これらの欠点を改善できると考えられる.

\section{摘 要}

さまざまな濃度のスクロース処理液が蕾切りカーネー ションの蕾生育および切り花品質に及ぼす影響を調査する
とともに，蕾生育中の切り花の各部位に打ける糖質濃度の 変化を解析した。

処理液のスクロース濃度は開花所要日数には大きく影響 しなかったが，スクロース濃度を高くすると，花径が大き くなり花色発現が促進された.

カーネーション切り花中には, スクロース, グルコース, フルクトース，ピニトール拉よびミオイノシトールが検出 された，自然生育区では，がく，葉，茎の糖質濃度はほぼ 一定に保たれていたが，花弁では開花にともないグルコー スとフルクトースの濃度が顕著に増加した。スクロース $0 \%$ 処理ではいずれの部位でもピニトール以外の糖質が 開花にともない著しく低下した。スクロース $5 \%$ 処理では 自然生育区と比較すると低い濃度で推移したが，糖質濃度 の低下は抑制され，花弁中のグルコースとフルクトース濃 度の上昇が認められた。自然生育区，0\%区，5\%区ともに ピニトール濃度はほとんど変化しなかった。

以上の結果から，スクロースは蕾切りカーネーション切 り花中の糖質濃度を増加させ，花の大きさを増大するとと もに花色発現を促進することが明らかとなった。

\section{引用文献}

Abou Dahab, A. M. 1967. Effects of light and temperature on growth and flowering of carnation (Dianthus caryophyllus L.). Meded. LandbouwHogeschool Wageningen 67: 1-68.

Cywińska, S. K., R. M. Rudnicki and D. Goszczyńska. 1978. The effect of exogenous growth regulators in opening tight carnation buds. Scientia Hortic. 9: 155-165.

Goszczyńska, D. and R. M. Rudnicki. 1983. Long-term cool storage of bud-cut carnations. Acta Hort. 141: 203-212.

Ichimura, K. and T. Hiraya. 1999. Effect of silver thiosulfate complex (STS) in combination with sucrose on the vase life of cut sweet pea flowers. J. Japan. Soc. Hort. Sci. 68: 23-27.

Ichimura, K., K. Kohata, M. Koketsu, M. Shimamura and A. Ito. 1998. Identification of pinitol as a main sugar constituent and changes in its content during flower bud development in carnation (Dianthus caryophyllus L.), J. Plant Physiol. 152: 363-367.

Ichimura, K. and M. Korenaga. 1998. Improvement of vase life and petal color expression in several cultivar of cut Eustoma flowers using sucrose with 8-hydroxyquinoline sulfate. Bull. Natl. Res. Veg., Ornam. Plants \& Tea 13: 31-39.

Ichimura, K., S. Ueyama and R. Goto. 1999. Possible roles of soluble carbohydrate constituents in cut rose flowers. J. Japan. Soc. Hort. Sci. 68: 534-539.

Kenis, J. D., S. T. Silvente and V. S. Trippi. 1985. Nitrogen metabolism and senescence-associated changes during growth of carnation flowers. Physiol. Plant. 65: 455-459.

Kofranek, A. M., D. S. Farnham, E. C. Maxie and J. Kubota. 1972. Long term storage of carnation buds. Flor. Rev. 151: 
29-30.

小山佳彦・宇田 明. 1994a. カーネーションのつぼ久開花 および品質に及ぼす温度, 照度, ショ糖濃度の影響. 園学雑. 63: 203-209.

小山佳彦・宇田 明. 1994b. つぼみ切りカーネーションの 貯蔵拈よび開花法. 園学雑. 63: 211-217.

McGuire, R. G. 1992. Reporting of objective color measurements. HortScience 27: 1254-1255.

Minakuchi, S., H. Watanabe and T. Kawasaki. 2004. Actual states of harvesting and shipping of carnations, and possibility of shipping regulation by bud anthesis acceleration (BAA). SASJ. 35: 165-172.

水口 聡・渡辺 久・川崎哲郎. 2005. カーネーションの 蕾開花促進に打ける採取ステージおよび温度が出荷ま での日数や切り花品質に及ぼす影響. 農業施設. 36 : 153-159.
水口 聡・渡辺 久・川崎哲郎. 2007. カーネーションの 蕾開花促進法に打ける糖質代謝と処理液中の糖質が切 り花品質に及ぼす影響. 近中四農研. (印刷中).

Parups, E. V. and A. P. Chan, 1973. Extension of vase-life of cut flowers by use of isoascorbate-containing preservative solutions. J. Amer. Soc. Hort. Sci. 98: 22-26.

Rudnicki, R. M., D. Goszczyńska and R. Tomasz. 1989. Bud opening and long term storage of spray carnations. Acta Hort. 261: 265-270.

Teklic, T., N. Paradzikovic and V. Vukadinovic. 2003. The influence of temperature on flower opening, vase life and transpiration of cut roses and carnations. Acta Hort. 624: 405-411.

Woodson, W. R. and H. Wang. 1987. Invertases of carnation petals. Partial purification, characterization and changes in activity during petal growth. Physiol. Plant. 71: 224-228. 